\begin{tabular}{|c|c|}
\hline & Volume \& Issues Obtainable at The Women University Multan \\
Annals of Social Sciences and Perspective \\
ISSN: 2707-7063, Volume 2, No.1 June 2021
\end{tabular}

\title{
Role of External Debt and Trade Deficit in Economic Performance of Pakistan
}

\author{
Noreen Safdar', Malka Liaquat ${ }^{2}$, Saima Bibi ${ }^{3}$
}

${ }^{1}$ Assistant Professor, Department of Economics, The Women University, Multan

${ }^{2}$ Assistant Professor, Institute of Management Sciences, The Women University, Multan.

${ }^{3}$ Research Scholar, Department of Economics, The Women University, Multan.

\begin{tabular}{ll}
\hline ARTICLE DETAILS \\
\hline History: & \\
Received: & February 22, 2021 \\
Review: & June 28, 2021 \\
Accepted: $\quad$ June 28, 2021 \\
Available Online: June 30, 2021
\end{tabular}

\section{Keywords:}

External Debt, Trade Deficit, Economic Growth.

\begin{abstract}
The purpose of this study is to examine influence of trade deficit and external debt on performance of economy of Pakistan during 1980-2017. GDP is used as dependent variables while trade deficit, gross capital formation, exchange rate, labor force, manufacturing value added, and total external debt are used as explanatory variable. The short-run, longrun association and stationarity of data amongst variables are obtained by applying vector error correction technique and Johansen Co-integration test. The study reveals that there is a statically important and negative influence of the trade deficit on GDP while total external debt also has a harmful impact on GDP. Moreover, results show that there is an optimistic and noteworthy connection among gross capital formation and GDP and Gross domestic product is positively influenced by Exchange rate, labor force and manufacturing value added. The association between total external debt and gross domestic product is negative and significant, it means when total external debit increases gross domestic product decrease. Government of Pakistan should create persistent strategies marked at differentiating economic actions so as to give nation prosperous sources of budget financing instead of trusting much on external borrowings.
\end{abstract}

(C) 2021 The Authors, Published by WUM. This is an Open Access Article under the Creative Common Attribution Non Commercial 4.0

Corresponding author's email address: malka.liaquat@wum.edu.pk

\section{Introduction}

External debt is part of a republic's debt that remained loaned out for imported investors like commercial banks, government or international financial institutes. These loans essentially 
remain compensated in cash in which credit existed. So as to produce required currency, borrowing state may sell and transfer things to investor's state. External debt is measured a significant, central financing source so that economies relay on to the Atta in growing or on to the additional public objects. While governments face shortage of local savings and foreign currencies required consequently external debt is suffered in situation of desirable reserves. In any economy debt is particular foundations of capital formation of financing so that debt is significant for management to borrow to encounter economic obligation in basis of scarcity. Therefore, government can close the incomes gap among saving and investment (Umaru et al., 2013).

In the developing country external debt shows equally undesirable and constructive part. The performance of export can either be affected or not affected by external debt. In the case of developing economies, external debt can be beneficial as it can be used in many developing projects like in building the infrastructure, in power points, in industry and also in agriculture sector. Many studies have shown that in low less usage of external debt, there is an optimistic influence of external dues on socio economic development of any economy, while excessive usage of external debt has undesirable relation through socio economic development.

A trade shortfall is a financial extent of international trade in which importations increased over the exports of the country. Outflow of local currency to foreign marketplaces is called trade deficit. It is similarly denoted to as a deleterious balance of trade.

Typically trade deficit arises when a state does not yield sufficient things for its populations. Customers are well-off sufficiently to obtaining extra things than the state products it means a deficit. Imports from other nations increase when production cannot meet demand. In the nation as foreign competition increases when rise in imported goods from other states, declines price of consumer goods. In local economy lesser prices support to decrease hazard situation of inflation. Rise in imports also rises collection of goods and services obtainable to people of a country. A rapidly emergent economy force imports extra as it increases to permit its people to consume more than state can yield. Subsequently, a trade deficit might point out a rising economy.

It is considered that trade deficit as the worldwide balance of trade. To elucidate influence and correlation amongst economic growth rate and trade deficit most policymakers and researchers use trade balances. In the country Trade shortfall is a horrible streak for long run financial development rate. Due to numerous reasons for instance variations in level of price, level of income, population, employment and numerous further aspects of a country created trade deficit. Finally, the balance of payment converts shortfall and external debt will rise when country payment is greater than receipts.

In any country trade shortfall is a significant macroeconomic sign by which financial performance is judged. Pakistan, India and Bangladesh fronting extraordinary trade shortfall involvement deprived financial well-being and are not exclusion to this. Identifying verses reason of trade deficit in economic literature. Unsuitable fiscal and monetary strategies can lead to trade shortfall from policy side. Trade deficit also increase when the external shockwaves like slowdown in major trading partners and oil dependency of the economy is higher. The exports demand falloffs leading to reduction in foreign exchange supply which devalues national money in the circumstance of slowdown in major trading partners. Again, domestic currency may depreciate in situation of high oil prices.

Pakistan is developing country which always faces the deficit due to political instability, 
corruption etc. Pakistan in several decades is upsetting from balance of payments deficit. For Pakistan Government, it is difficult to control balance of payment of trade and external money by way of associated to national money. Trade shortfall is a major cause that has a very harmful effect on Pakistan economy. Trade deficit are faced by most developed countries. On the economy Trade deficit have the negative effect. Trade deficit occurred when imports higher than exports. Measures undertaken by the Economic Monitoring Committee (EMC) and the Pakistan State Bank have failed to significantly reduce the country's import volume. Pakistan's rapidly draining government's Forex reserves are difficult to manage trade balance payments, which is why foreign currency versus home currency is strengthened, resulting in imports of the goods and services to become more exclusive and expensive as compared to the exports and causing home currency devaluation and balance of payments deficit.

The central purpose of existing study is to see influence of external debt, trade shortfall on financial progress of Pakistan through further control variables alike manufacturing value added, gross capital formation exchange rate and labor force, the external debt difficulties are one of central experiments tackled by emerging states like Pakistan during last fifty years.

\section{Literature Review}

Zafer et al. (2015) studied impact of openness of trade and debt on financial growth some selected countries this study applied panel data during 1980 to 2012. GDP was applied as a dependent variable although the trade openness and the debt were employed as explanatory variables. To check stationarity of data the unit root test was used in this assessment, the consequences specified a constructive association among trade openness and development while external debt had significant and adverse impact economic development and debt.

Iqbal et al. (2015) documented the role of external debt and external trade on financial development of Pakistan by applying time series during the period 1972-2013. The variables such as debt servicing, external debt, export, import and real GDP growth were applied for this assessment. The ordinary least square (OLS) technique was applied for this estimation. The result indicated that external debt had constructive and noteworthy influence on economic development although debt servicing had adverse influence on economic development. This study also suggested that export had an optimistic and noteworthy influence on economic development although import could not find significant effect on economic development.

Noonari et al. (2015) found association among net external liabilities and economic development of Pakistan for time span 1973 to 2012. Augmented Dickey-Fuller (ADF) and Unit root tests was useful for this determination. The variable such as Gross Domestic Product (GDP) was applied as a dependent variable whereas external debt, Debt Service, Gross Capital Formation and export were applied as independent variables for this analysis. The consequence of study showed that education enrolment, net external liabilities, export and gross capital formation had an optimistic and noteworthy link through GDP although debt service had no significant relationship.

Azeez et al. (2015) explored association among foreign direct investment and external debt on development of Nigeria by taking the yearly time series data for period of 1990 to 2013. In this study, gross domestic product was taken as a dependent variable although foreign direct investment exchange rate and external debt were used as independent variables for this estimation. The data was taken from Central Bank of Nigeria (CBN) and Statistical Bulletin. 
Error Correction Modelling (ECM), Johansen co-integration tests and Augmented Dickey Fuller (ADF) unit root were used to test the stationary of variables. The result presented that the external debt had undesirably and unimportantly associated with economic development although foreign direct investment also had destructively but meaningfully connected with economic growth.

Jebran at al. (2016) analyzed effects of public debt on economic growth for Pakistan through taking yearly time series data during 1972 to 2012. The data for numerous variables of study was attained from State bank of Pakistan and WDI. The auto regressive distributed lag model (ARDL) and Bounds testing model had been applied to analyses long and short run relationship among growth of economy and public debt. The results showed the noteworthy opposing influence of external debt on GDP in long run and in short run. The study moreover showed that noteworthy adverse influence of external debt on GNP in long run and in short run.

Naeem at al. (2016) found association among external debt and external rate of interest in Pakistan through taking time series data during 1972- 2013 and Model of Autoregressive Distributed Lag" (ARDL) method used for this estimation. The variables such as External Debt, Debt Services, Interest Payment, Budget Deficit, GDP and Exchange Rate were used for this study. The long-run results indicated that interest payments, budget deficit and GDP had a noteworthy and optimistic influence on external debt although exchange rate had an adverse and insignificant influence on external debt. The results showed budget deficit had an insignificant and harmful influence on external debt while exchange rate had undesirable and insignificant influence on external debt in short run in case of Pakistan.

Khan et al. (2016) investigated the relations between External Debts, Exports, Budget Deficit, Imports and GDP for Pakistan economy through using unit root and Autoregressive Distributed Lag (ARDL) methods for this estimation over the period of 1999 to 2014. So, Exports, Budget Deficit, External Debts and Imports were used as an independent variables and Real Gross Domestic Product Growth rate was applied as a dependent variable in this study. The results showed that ARDL model had been engaged to test long run link between variables such as Budget Deficit, External Debts, GDP, Exports and Imports.

Al-Fawwaz (2016) estimated main factors manipulating external debt in Jordan by taking time series data during 1990 to2014. The model of Autoregressive Distributed Lag (ARDL) had been applied for this analysis. The variable such as external debt was utilized as a dependent and exchange rate, gross domestic product per capital, trade openness and term of trade were applied as independent variables for this assessment. The consequence presented that trade variable had an optimistic and statistically noteworthy outcome on external debt in long run, and GDP per capita had an adverse and statistically significant influence on external debt.

Siddique et al. (2017) established influence of external debt on of economic growth in Pakistan. For time span 1975 to 2015, time series data was applied. The variables such as gross fixed capital formation, GDP per capita, human capital, external debt and labor force were used for the estimation. The autoregressive lag distributed bound testing for cointegration technique was applied after checking the stationary properties. The result showed that external debt had a major and adverse effect on development of economy of Pakistan while human capital and trade were increasing factors of growth of economy in long run along with in short run. 
Shamim et al. (2017) investigated associations between binary variables, exports performance and external debt within extent of Pakistan. The data applied for assessment were was taken through yearly time series during time period of 1972 to 2014. The channel of variables used in this study such as export, GDP, real exchange rate and external debt and co-integration test and techniques of Error correction applied for this purpose. The result indicated that there was an important adverse association among external debt and export performance in Pakistan

Hassan et al. (2017) explored that the long run association among trade deficit and its elements in Pakistan, Bangladesh and India by taking yearly time series data during 1972 to 2013. Dickey Fuller, ARDL co-integration approach and unit root tests was applied to test stationary of variables. The conclusions that reduction of real effective exchange rate importantly decreased trade shortfall in Pakistan and Bangladesh. The result showed that trade deficit could be enhanced by aiming per capita income, real active exchange rate and money supply in Pakistan, India and Bangladesh.

Zahir (2018) investigated relationship among the foreign direct investment, trade deficit, economic development and external debt of Pakistan during time span 1981 to 2017. The variables such as foreign direct investment, trade deficit, gross domestic product and external debt used for this analysis. The used time series data and different technique such as Ordinary least squares (OLS), correlation methods employed for this estimation. The result depicted that direct investment and trade shortfall had optimistic and irrelevant association through growth of economy whereas external debt had also directed along with noteworthy effect on Pakistan's gross domestic product.

Ampah et al. (2018) observed association among capital flight and external debt in Seriously Indebted Deprived Republics (HIPC) in sub- Saharan Africa. This study used data during the period from 1990 to 2012. Autoregressive Distributed Lag (ARDL) model had been applied for this assessment. The variables such as external debt, capital flight, Gross Domestic Product (GDP) inflation, Political Stability, Financial Development and budget deficit were used for study. The result showed that External debt optimistic and had statistically noteworthy impact on capital flight for all of sub-regions in both short run and long run.

\section{Data \& Methodology Data Source}

In this study, annual data has been used from Pakistan Economic Survey, hand book of statistics and WDI. Econometric analysis uses the data from the period 1980 to 2017 in order to inspect the association amongst variables. The selection of time period is due to convenience of accurate data on both dependent and independent variables.

\section{Model specification}

Selection of model for accurate results is an important step for analysis. In this study to find association among trade deficit, external debt, and economic performance of Pakistan model is characterize below

$$
\mathrm{GDP}=\beta 0+\beta_{1} \mathrm{GCF}+\beta_{2} \mathrm{TDF}+\beta_{3} \mathrm{EXR}+\beta_{4} \mathrm{LF}+\beta_{5} \mathrm{MNVA}+\beta_{6} \mathrm{TED}+\varepsilon_{\mathrm{i}}
$$

Whereas, GDP is Gross domestic product while GCF, TDF, EXR, LF, MNVA and TED are showing Gross capital formation, Deficit, Exchange rate, Labor force, manufacturing value 
added, and Total external debt. This study utilizes time series data for year 1980 to 2017 .

\section{Results \& Discussions}

\section{A. Unit Root Test}

Augmented-Dickey Fuller assessment is applied to inspect stationary of all selected variables. If all variables are being integrated in order to I (1) then we used Johansen co-integration test.

Table 1: Unit Root Results

\begin{tabular}{|c|c|c|c|c|c|c|c|}
\hline & \multicolumn{2}{|l|}{ Level } & \multicolumn{2}{|c|}{$1^{\text {st }}$ difference } & \multicolumn{3}{|c|}{$2^{\text {nd }}$ difference } \\
\hline variables & Intercept & $\begin{array}{l}\text { Trend \& } \\
\text { Intercept }\end{array}$ & Intercept & $\begin{array}{l}\text { Trend \& } \\
\text { intercept }\end{array}$ & Intercept & $\begin{array}{l}\text { Trend \& } \\
\text { intercept }\end{array}$ & Results \\
\hline GDP & $\begin{array}{l}4.519224 \\
(1.0000)\end{array}$ & $\begin{array}{l}0.595336 \\
(0.9992)\end{array}$ & $\begin{array}{l}- \\
3.674452 \\
(0.0089)\end{array}$ & $\begin{array}{l}- \\
5.933578 \\
(0.0001)\end{array}$ & ......... & & $\mathrm{I}(1)$ \\
\hline TDF & $\begin{array}{l}0.722788 \\
(0.9911)\end{array}$ & $\begin{array}{l}- \\
0.737014 \\
(0.9625)\end{array}$ & $\begin{array}{l}- \\
5.659997 \\
(0.0000)\end{array}$ & $\begin{array}{l}- \\
6.180201 \\
(0.0001)\end{array}$ & ....... & ....... & $\mathrm{I}(1)$ \\
\hline GCF & $\begin{array}{l}2.512103 \\
(1.0000)\end{array}$ & $\begin{array}{l}- \\
0.120480 \\
(0.9925)\end{array}$ & $\begin{array}{l}- \\
4.262095 \\
(0.0019)\end{array}$ & $\begin{array}{l}- \\
5.168256 \\
(0.0009)\end{array}$ & ......... & $\ldots \ldots$ & $\mathrm{I}(1)$ \\
\hline EXR & $\begin{array}{l}- \\
2.370941 \\
(0.1568)\end{array}$ & $\begin{array}{l}- \\
0.855525 \\
(0.9503)\end{array}$ & $\begin{array}{l}- \\
3.947575 \\
(0.0045)\end{array}$ & $\begin{array}{l}- \\
4.465368 \\
(0.0058)\end{array}$ & $\ldots \ldots$ & $\ldots \ldots$ & $\mathrm{I}(1)$ \\
\hline LF & $\begin{array}{l}4.072808 \\
(1.0000)\end{array}$ & $\begin{array}{l}- \\
1.394557 \\
(0.8461)\end{array}$ & $\begin{array}{l}- \\
4.165553 \\
(0.0024)\end{array}$ & $\begin{array}{l}- \\
6.160797 \\
(0.0001)\end{array}$ & $\ldots \ldots$ & $\ldots .$. & $\mathrm{I}(1)$ \\
\hline MNVA & $\begin{array}{l}1.347611 \\
(0.9984)\end{array}$ & $\begin{array}{l}- \\
0.558234 \\
(0.9754)\end{array}$ & $\begin{array}{l}- \\
2.316147 \\
(0.1729)\end{array}$ & $\begin{array}{l}- \\
8.104941 \\
(0.0000)\end{array}$ & $\ldots \ldots$ & 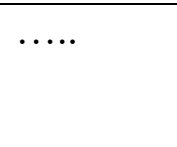 & $\mathrm{I}(1)$ \\
\hline TED & $\begin{array}{l}0.852773 \\
(0.9936)\end{array}$ & $\begin{array}{l}- \\
1.622475 \\
(0.7634)\end{array}$ & $\begin{array}{l}- \\
4.562310 \\
(0.0008)\end{array}$ & $\begin{array}{l}- \\
4.796554 \\
(0.0025)\end{array}$ & $\ldots \ldots$ & $\ldots .$. & $\mathrm{I}(1)$ \\
\hline
\end{tabular}

Source: Author's calculation EViews 9

By applying Augmented-Dickey fuller test, table displays that all variables lie on 1st difference and according to these results we used Johansen co- integration technique for further estimating the relationships among selected variables.

\section{B. Lag Length Selection}

Johansen Co-integration test includes collection of suitable lag length exhausting accurate information norms. The Hannan- Quinn information criterion, final Prediction error and Akaike information norm is used in our study for selecting lag length.

Table 2: Lag Length Variety

\begin{tabular}{lllllll}
\hline Lag & LogL & LR & FPE & AIC & SC & HQ \\
\hline 0 & -715.0471 & NA & $1.96 e+09$ & 41.25983 & 41.57090 & 41.36722 \\
\hline 1 & -448.2687 & 411.6009 & 8166.211 & 28.91536 & $31.30391 *$ & 29.67441 \\
\hline
\end{tabular}




\begin{tabular}{lllll}
\hline $2 \quad-362.8139 \quad 97.662669 *$ & $1452.611 *$ & $26.73222 *$ & 31.39827 & $28.34294 *$ \\
\hline *specifies lag order selected by criterion & & & \\
LR: sequential modified LR test statistic (each test at 5\% level) & & \\
FPE: Final prediction error & & & \\
AIC: Akaike information criterion & & \\
SC: Schwarz information criterion & & \\
HQ: Hannan- Quinn information criterion & & \\
\hline
\end{tabular}

\section{No. of Co-integration Vectors}

The estimation has created numerous co-integration equation by suggested statistic and extreme Eigen value statistics. Bestowing to probability assumed in tables III and IV study discards null hypothesis that there is no co-integrated vector, there is furthermost 1 cointegrated vector (At most 1 ) there is furthermost 2 co-integrated vectors (At most 2), there is furthermost 3 co-integrated vectors (At most 3), there is furthermost 4 co-integrated vectors (At most 4), there is 5 co-integrated vectors (At most 5). It funds that there are 6 cointegrated vectors in the long run consequences. Its demonstrations great relationship among independent and dependent variables applied in present assessment.

Table 3: Unrestricted Co-integration Rank Test (Trace)

\begin{tabular}{|c|c|c|c|c|}
\hline $\begin{array}{l}\text { Hypothesized } \\
\text { No. of CE(s) }\end{array}$ & Eigenvalue & $\begin{array}{l}\text { Trace } \\
\text { Statistic }\end{array}$ & $\begin{array}{l}0.05 \\
\text { Critical Value }\end{array}$ & Pro. ** \\
\hline None $*$ & 0.962854 & 314.6898 & 134.6780 & 0.0000 \\
\hline At most $1^{*}$ & 0.866858 & 202.7311 & 103.8473 & 0.0000 \\
\hline At most $2^{*}$ & 0.819585 & 134.1757 & 76.97277 & 0.0000 \\
\hline At most $3^{*}$ & 0.693716 & 75.95094 & 54.07904 & 0.0002 \\
\hline At most $4^{*}$ & 0.383600 & 35.72073 & 35.19275 & 0.0438 \\
\hline At most 5 & 0.308610 & 19.26953 & 20.26184 & 0.0680 \\
\hline At most 6 & 0.179384 & 6.721785 & 9.164546 & 0.1419 \\
\hline
\end{tabular}

Source: Author's calculation's E- views

Table III shows the long run correlation among dependent variable gross domestic product and independent variables Trade deficit, gross capital formation, exchange rate, labor force, manufacturing value added and total external debt and co-integration among these variables. In the first column explain the Hypothesized value second represent Eigenvalue. Third column shows Trace Statistic and fourth column illustrates critical value at 0.05 levels. The next column shows the probability of these variables.

The values of first four trace statistics are greater than critical value. The trace statistic values such as $314.68,202.73,134.17,75.95$ and 35.72 are greater than critical values as 134.67, 103.86, 76.97, 54.07 and 35.19. While it is obvious that last two trace statistics values 19.26 and 6.72 are less than the critical value 20.26 and 9.16 .

Table 4: Unrestricted Co-integration Rank Test (Maximum Eigenvalue)

\begin{tabular}{lllll}
\hline $\begin{array}{l}\text { Hypothesized } \\
\text { No. of CE(s) }\end{array}$ & Eigenvalue & $\begin{array}{l}\text { Max- Eigen } \\
\text { Statistic }\end{array}$ & $\begin{array}{l}0.05 \\
\text { Critical Value }\end{array}$ & Pro. ** \\
\hline None $*$ & 0.962854 & 111.9587 & 47.07897 & 0.0000 \\
\hline At most $1 *$ & 0.866858 & 68.55541 & 40.95680 & 0.0000 \\
\hline
\end{tabular}




\begin{tabular}{lllll}
\hline At most 2* & 0.819585 & 58.22480 & 34.80587 & 0.0000 \\
\hline At most 3* & 0.693716 & 40.23021 & 28.58808 & 0.0011 \\
\hline At most 4 & 0.383600 & 16.45120 & 22.29962 & 0.2674 \\
\hline At most 5 & 0.308610 & 12.54775 & 15.89210 & 0.1564 \\
\hline At most 6 & 0.179384 & 6.721785 & 9.164546 & 0.1419 \\
\hline
\end{tabular}

Source: Author's calculation's E- views 9

In this table first column shows Hypothesized value, second column illustrates Eigenvalue, third column represent Max- Eigen statistic, fourth column show the critical values at 0.05 levels and next column illustrates probability of these variables. It is obvious that first four extreme Eigen statistics values are greater than critical values. As Max- Eigen values 111.95, $68.55,58.22$ and 40.23 are greater than critical values $47.07,40.95,34.80,28.58$ while all these values reject the hypothesis at 0.05 levels. Next last three Max-Eigen statistics values $16.45,12,54$ and 6, 72 are less than critical values 22.29, 15, 89 and 9.16. All these values accept the hypothesis at the $5 \%$ level.

\section{Test of Johansen Co-integration for Long Run Results}

The Johansen co-integration test is applied to test long run association among dependent and independent variables. The consequences are set below in table V.

Table 5: Long run Consequences of Johansen

\begin{tabular}{lllll}
\hline Variables & Coefficient & Standard Error & T- Statistics & Conclusion \\
\hline TDF & -2.952875 & 0.38163 & 7.73746 & Significant \\
\hline GCF & 5.215389 & 0.54299 & 9.60489 & Significant \\
\hline EXR & 0.175676 & 0.02500 & -7.02586 & Significant \\
\hline LF & 0.672382 & 0.23746 & -2.83151 & Significant \\
\hline MNVA & 14.98039 & 0.59153 & -25.3250 & Significant \\
\hline TED & -0.243772 & 0.19503 & 1.24992 & Insignificant \\
\hline
\end{tabular}

The long run estimates of external debt and trade deficit model are represented in table V. First column used in the table there is variables column while coefficients, standard errors and t-statistics are explained in 2nd 3rd and 4th columns. Next column accomplishes noteworthy and irrelevant associations of completely variables and total external debt is irrelevant although all other variables are important. In this assessment GDP used in place of a dependent variable. Signs on coefficient of independent variables demonstrates how these variables are connected with GDP whether they are negatively related or positively related.

The coefficient of variable Trade deficit is statistically momentous as its value is -2.953 and negatively related to GDP in this study. T- Statistic value of Trade deficit is 7.737. Our consequences are reliable through earlier finding of (Ahmad, Hayat and Luqman (2013). Gross capital formation positive related with GDP and statistically significant as coefficient value is $\mathbf{- 5 . 2 1 5}$. While t-statistics value of gross capital formation is 9.604 .

In this study exchange rate statistically significant and positively related to GDP. Its coefficient value is 0.175 and $t-$ statistic is $-7,025$. The consequence indicated that exchange rate has a optimistic association through GDP. Rise in rate of exchange carries about a rise in Gross Domestic Product. A rise in rate of exchange (i.e., money devaluation) inspires export, as external money could effortlessly remain replaced through fewer worth to acquisition from 
that nation, but depresses importation. As a result, demand for nearby manufactured things rises. Subsequent rise in demand, rises in manufacture and this might be consequence in employment, and ultimate rise in Gross Domestic Product. Our consequences are reliable through many prior findings of [Nwannebuike, Ike and Onuka (2016)].

While MNVA statistically significant and positively relate with GDP in this study. In the MNVA coefficient values is 0.672 , while a t-statistic value is -2.831 . The worth of imports essential deducted to certify that only outlay on domestic goods is calculated in GDP. But obtaining of imported goods and service has no direct effect on GDP. It is clear that buying of local goods and services rises GDP as it increases local product. Our results are consistent with many previous finding [Haq, Perveen, and Amin, (2017)].

While LF statistically significant and positively relate with GDP in this study. In the LF coefficient value is 14.980 while a t-statistic value is -25.325 . Our results are consistent with many previous finding [Paudel and Perera, (2009); Hassan and Butt, (2008)].

TED is also negatively related with GDP as its coefficient value is -0.243 . Statistically insignificant and its t-statistic value is 1.249. Our results are consistent with many previous finding [Nwannebuike, Ike and Onuka, (2016); Atique and Malik, (2012); Paudel and Perera, (2009)].

\section{Model of Vector Error Correction (short run consequences)}

Table VI explains short run consequences by means of vector error correction model. Deprived of supports values show the short run factors, round brackets values show the standard errors and square brackets values explain t-statistics. In short run results the most significant object is the quickness of modification term. It illustrated how abundant spell would be used through economy to extent at the long run stability. Mark of Negative shows the quickness of the amendment term, economy will intersect toward long term stability. The coefficient value is statistically significant in the short run.

Table 6: Vector Error Correction short run results

\begin{tabular}{ll}
\hline Error Correction & $\mathrm{D}(\mathrm{GDP})$ \\
\hline CointEq1 & -0.774948 \\
& $(0.23370)$ \\
& {$[-3.31596]$} \\
\hline $\mathrm{D}(\mathrm{GDP}(-1))$ & 1.202375 \\
& $(0.35447)$ \\
& {$[3.39201]$} \\
\hline $\mathrm{D}(\mathrm{GDP}(-2))$ & 1.073121 \\
& $(0.31689)$ \\
& {$[3.38646]$} \\
\hline $\mathrm{D}(\mathrm{TDF}(-1))$ & 2.068899 \\
& $(1.36234)$ \\
& {$[1.51863]$} \\
\hline $\mathrm{D}(\mathrm{TDF}(-2))$ & 1.116217 \\
& $(1.18851)$ \\
& {$[0.93917]$} \\
\hline $\mathrm{D}(\mathrm{GCF}(-1))$ & -1.029229 \\
& $(1.21491)$ \\
\hline
\end{tabular}




\begin{tabular}{|c|c|}
\hline & {$[-0.84716]$} \\
\hline \multirow[t]{3}{*}{$\mathrm{D}(\mathrm{GCF}(-2))$} & 0.169337 \\
\hline & $(1.52182)$ \\
\hline & {$[0.11127]$} \\
\hline \multirow[t]{3}{*}{$\overline{\mathrm{D}(\mathrm{EXR}(-1))}$} & 0.081855 \\
\hline & $(0.15776)$ \\
\hline & {$[0.51887]$} \\
\hline \multirow[t]{3}{*}{$\mathrm{D}(\mathrm{EXR})-2))$} & -0.182976 \\
\hline & $(0.17014)$ \\
\hline & {$[-1.07544]$} \\
\hline \multirow[t]{3}{*}{$\mathrm{D}(\mathrm{LF}(-1))$} & 2.598282 \\
\hline & $(2.53696)$ \\
\hline & [1.02417] \\
\hline \multirow[t]{3}{*}{$\mathrm{D}(\mathrm{LF}(-2))$} & -7.419887 \\
\hline & (3.07230) \\
\hline & {$[-2.41509]$} \\
\hline \multirow[t]{3}{*}{$\mathrm{D}(\mathrm{MNVA}(-1))$} & -8.938433 \\
\hline & $(2.63263)$ \\
\hline & {$[-3.39525]$} \\
\hline \multirow[t]{3}{*}{$\mathrm{D}(\mathrm{MNVA}(-2))$} & -6.732651 \\
\hline & (1.90703) \\
\hline & {$[-3.53043]$} \\
\hline \multirow[t]{3}{*}{$\overline{\mathrm{D}(\mathrm{TED}(-1))}$} & 2.774775 \\
\hline & $(0.82575)$ \\
\hline & [3.36033] \\
\hline \multirow[t]{3}{*}{$\mathrm{D}(\mathrm{TED}(-2))$} & 0.516349 \\
\hline & $(0.75363)$ \\
\hline & {$[0.68515]$} \\
\hline R-squared & 0.771104 \\
\hline Adj. R-squared & 0.602444 \\
\hline F- statistic & 4.571948 \\
\hline
\end{tabular}

\section{Conclusion and Policy Implication}

The study explains how external debt and trade deficit affect economic performance of Pakistan by taking time series data during 1980 to 2017. The ADF unit root test is applied to check data stationarity, if all variables are integrated at first difference then we apply vector error correction and Johansen co-integration method for long run and short run association of independent and dependent variables.

The variables taken for this estimation are gross domestic product occupied by means of dependent variable although trade deficit, gross capital formation, exchange rate, labor force, manufacturing value added and total external debt taken as independent variables. Association among gross domestic product and trade deficit is adverse. When trade deficit increases, gross domestic product decrease. There is optimistic association among gross capital formation and gross domestic product, increase in GDP due to rise in gross capital formation. Rate of Exchange has optimistic and noteworthy relation through GDP. When GDP, rate of exchange increases, also increase. Relationship between labor force and gross domestic product is constructive and important. There is increase in gross domestic product due to increase labor force. 
Manufacturing has constructive and noteworthy impact on gross domestic production, rise in GDP with increase in manufacturing. The association between total external debt and gross domestic product is positive and significant, it means when total external debit increases gross domestic product decrease total.

The consequences of the study are accommodating to put forward specific optimal policy implications to improve the external debt and trade shortfall in Pakistan. On foundation of consequences accomplished by this study, some applicable policies can be recommended.

In order to increase the growth of economy, Pakistan government should reduce foreign obligation as it generates economic problems.

Government should emphasis on policies that rise foreign direct investment inflows and decrease external and internal debt.

The government should provide a policy structure that generates a credible environment for shareholders' sureness in financing in country both local and foreign.

The greatest features distressing trade shortfall in Pakistan are real active rate of exchange and GDP per capita. In order to reduce trade deficits in Pakistan, devaluation of the increase per capita income, real effective rate of exchange and control supply of money are useful.

\section{References}

Abbas, M., \& Raza, H. (2013). Effects of Trade Deficit on the Economy of Pakistan. Interdisciplinary journal of contemporary research in business, 4(11), 176-215.

Al-Fawwaz, T. M. (2016). Determinants of External Debt in Jordan: An Empirical Study (1990-2014). International Business Research, 9(7), 116-123.

Atique, R., \& Malik, K. (2012). Impact of domestic and external debt on the economic growth of Pakistan. World Applied Sciences Journal, 20(1), 120-129.

Awan, A., Asghar, N., \& Rehman, H. U. (2011). The impact of exchange rate, fiscal deficit and terms of trade on external debt of Pakistan. Australian Journal of Business and Management Research, 1(3), 10-24.

Ahmed, N., Ahmed. U., Hayat, F.M., \& Luqman. M. (2013) Relationship between Trade Deficit and Economic Growth in Pakistan: An Econometric Investigation, Australian Journal of Basic and Applied Science, 7 (7), 963-967.

Bhatta, G. (2003). An Assessment of the Impact of External Debt on Economic Growth of Nepal. NRB Economic Review, 15, 243-262.

Cholifihani, M. (2008).A cointegration analysis of public debt service and GDP in Indonesia.Journal of Management and social sciences, 4(2), 68-81.

Ezeabasili, V. N., Isu, H. O., \& Mojekwu, J. N. (2011). Nigeria's External Debt and Economic Growth: An Error Correction Approach. International Journal of Business Management, 6(5), 156-170. http://dx.doi.org/10.5539/ijbm.v6n5p156

Hassan, M. S., Wajid, A., \& Kalim, R. (2017). Factors affecting trade deficit in Pakistan, India and Bangladesh. Economia Politica, 34(2), 283-304.

Hassan, A., \& Butt, S. (2008). Role of trade, external debt, labor force and education in economic growth empirical evidence from Pakistan by using ARDL approach. European Journal of Scientific Research, 20(4), 852-862.

Hameed, A., Ashraf, H. \& Chandhary, M. A. (2008). External Debt and its Impact on Economic Business Growth in Pakistan, International Research Journal of Finance and Economics, ISSN 1450 - 2887, issue 20:132 - 140 
Iqbal, A., Turabi, Y. R., Hussain, J., \& Laghari, A. (2015).Investigating the role of external trade and external debt on the economic growth of Pakistan. IBT Journal of Business Studies, 11(1), 27-39.

Jibran, K., Ali, A., Hayat, U., \& Iqbal, A. (2016). Public debt and economic growth in Pakistan: A reassessment. Pakistan Business Review, 18(2), 307-324.

Kasidi, F., \& Said, A. M. (2013). Impact of external debt on economic growth: A case study of Tanzania. Advances in Management and applied economics, 3(4), 59-82.

Khan, I., Mughal, K., Zia, F., \& Usman, F. Do the GDP, Budget Deficit, External Debts, Exports and Imports affect each other for Pakistan: An ARDL Approach?34-45.

Loganathan, N., Sukemi, M. N., \& Sanusi, N. A. (2010). External Debt and Macroeconomics Performance in Malaysia: Sustainable Or Not? Global Economy and Finance Journal, $3(2), 122-132$.

Malik, S., Hayat, M. K., \& Hayat, M. U. (2010). External debt and economic growth: Empirical evidence from Pakistan. International Research Journal of Finance and Economics, 44(44), 1450-2887.

Naeem, M. Z., Akhlaque, S., \& Ashiq, R. (2016). External Debt and External Rate of Interest: An Empirical Analysis of Pakistan. Bulletin of Business and Economics (BBE), 5(3), 116-125.

Noonari, S., Memon, M. I. N., Peerzado, M. B., Shah2 Qurat-ul-ain, S. T., Ahmed, M. S. A. W. A., \& Sargani, C. G. R. Net External Liabilities and Economic Growth: A Case Study of PakistanVol.8, 36-41.

Nwanne, T. F. I. (2018). Assessing the effect of external debt servicing and receipt on exchange rate in Nigeria. International Journal of Economics and Finance, 7(9), 278286.

Okech, T. C., Mweni, F. T., \& Njuguna, A. G. (2016). The Effect of External Debt on Inflation Rate in Kenya, 1972-2012.

Ogunmuyiwa, M. S. (2011). Does external debt promote economic growth in Nigeria?. Current Research Journal of Economic Theory, 3(1), 29-35.

Paudel, R. C., \& Perera, N. (2009). Foreign debt, trade openness, labor force and economic growth: Evidence from Sri Lanka.

Paudel, R., \& Shrestha, M. B. (2006). The role of external debt, total trade and labour force in economic growth: the case of Nepal. The Business Review, Cambridge, 5(2), 130136.

Poirson, M. H., Ricci, M. L. A., \& Pattillo, M. C. A. (2004). What are the channels through which external debt affects growth? (No. 4-15). International Monetary Fund.

Rauf, A., \& Khan, A. Q. (2011).An empirical study to find the relationship between Trade deficit and Budget Deficit in Pakistan.Academic Research International, 1(3), 36.

Saleh, A. S. (2006). Long-run linkage between budget deficit and trade deficit in Lebanon: Results from the UECM and bounds tests. IIUM Journal of economics and management, 14(1), 29-48.

Schclarek, A. (2004). Debt and economic growth in developing and industrial countries.Lund University Department of Economics Working Paper, 2005, 34.

Shah, M., \& Pervin, S. (2012). External public debt and economic growth: empirical evidence from Bangladesh, 1974 to 2010.

Sheikh, M. R., Chaudhry, I. S., \& Faridi, M. Z. (2013). Defense expenditures and external debt: evidence from Pakistan and India. Pakistan Economic and Social Review, 159177.

Sulaiman, L. A., \& Azeez, B. A. (2012).Effect of external debt on economic growth of Nigeria. Journal of Economics and Sustainable Development, 3(8), 71-79.

Siddique, H. M. A., Ullah, K., \& Haq, I. U. (2017).External debt and economic growth Nexus 
in Pakistan. International Journal of Economics and Empirical Research, 5(2), 73-77.

Shafi, K., Hua, L., Idrees, Z., \& Nazeer, A. (2015). Relationship of debt and economic growth: The comparative study between Pakistan and India. International Journal of Service Science, Management and Engineering, 2(1), 9-12.

Tufail, M. K., Anwar, S., Raza, S. H., \& Abbas, K. (2014). Effect of budget deficit on trade deficit in Pakistan (a time series analysis). Journal of Finance and Economics, 2(5), 145-148.

Ward, H. P., Ricci, L. A., \& Pattillo, C. A. (2002). External debt and growth (No. 02/69). International Monetary Fund.

Wijeweera, A., Drollery, B., \& Pathberiya, P. (2005). Economic growth and external debt servicing: a cointegration analysis of Sri Lanka, 1952 to 2002. University of New England working paper series in economics, 8.

Zahir, S. Impact of trade deficit, foreign direct investment and external debt on economic growth of Pakistan; a time series analysis. 